\title{
Mechanism of Land-Use Changes in Yuqi Township, Wuxi City, China
}

\author{
JI Zengmin \\ Department of Culture-Information Studies, Sugiyama Jogakuen University, \\ Nagoya 464-8662, Japan
}

\begin{abstract}
This paper will begin with a discussion of the particular characteristics of the area of our focus, namely Yuqi Town in a rural area of the Yangtze Delta. As an aid to understanding land-use patterns and changes in that area, satellite imagery has been utilized, and the results and our analysis thereof are reproduced in the Figures chart herein. The paper will then proceed to analysis and discussion of the guiding plan for the area, entitled "Comprehensive Land Use Plan for Yuqi Town, 1997-2010," to determine the actual results thus far of the implementation of this plan. It will conclude with an examination of the mechanisms existing for determining the extent to which the provisions of the plan have actually been put into effect.
\end{abstract}

Key words: land-use change, mechanism, township level, Wuxi City, China

\section{Introduction}

In order to have a clear and detailed picture of land-use changes in the increasingly urbanized Chinese countryside, and to pinpoint the structural and legal characteristics of such changes, a two-pronged approach is necessary. One element is a macro view based on data regarding land-use changes; the other is a careful consideration of the nature of the "township" as the most fundamental level of rural administration. The main reasons for such an approach can be summarized as follows:

1) During the 20-year period from 1978 to 1998 , the percentage of people living in cities ${ }^{1}$ of China rose from being $12.4 \%$ of the entire population to $16.8 \%$ - a mere $4.4 \%$ increase. During the same period, however, the percentage of people living in towns (or townships, to use the precise term) rose by a full $8.1 \%$, from $5.5 \%$ of the total population to $13.6 \%$. This means that China's urbanization has largely been the result of the movement of people from rural areas to townships (primarily the central areas of towns, referred to below as the "town proper"). The central role of the township is further illustrated by statistics related to the expansion of built-up areas: while the total amount of built-up areas was $22,000 \mathrm{~km}^{2}$ in the cities as of 1999 , it had reached $44,110 \mathrm{~km}$ in the townships - fully twice as much built-up space.

2) Over the course of the next 20 years, it is estimated that 55 million inhabitants of rural areas will move to townships, while only between 45 and 48 million will move to the cities (Nian and Yao 2002). In the "peasant society" that China still is, this increasing concentration of a large part of the rural population in the townships (as opposed to cities) reflects national policy (Ji 2001).

3) Changes in land use from "rural" to "urban" and a similar transformation of the population have taken place in the townships with the active intervention of the local authorities. Therefore, townships have played the central role in the process of consolidating districts for housing or industrial use and increasing the overall efficiency of land use. At the same time the process of urbanization is seen in the builtup area of central districts within those townships.

4) In clear contrast to the county and higherlevel administrative subdivisions, which can be said to be largely formal in nature, the township possesses real power to affect the economy, the culture, and the daily lives of its inhabitants. In the case of land use, for example, the county is nothing more than a regulatory body, 
while the township deals closely with its residents in all matters related to land use, starting with the transfer of land from agricultural to other purposes, and directly oversees implementation of measures. Thus, by examining the situation in townships, it should be possible to understand the process of land-use change and the precise mechanisms in place for carrying out such changes.

Recognizing the above, the present author has analyzed the situation in the Yangtze River Delta, an area of particularly rapid and dramatic land-use change (Ji and Torii 1999). They focused on macroscale analysis - the Delta as a whole-as well as mesoscale: expansion of towns proper and the background to this in greater metropolitan Xishan ${ }^{2}$ (Ji and Torii 2000; Ji 2002). The purpose of this paper is to clarify the actual changes in different approaches to land use at township level, as "part" of the "whole" constituted by the above macroscale analysis.

Land use change in townships is often discussed in "Theory of Small-Scale Towns." ${ }^{3}$ Tanimura (1995) categorized the business types into creation of new towns and further development of new townships, and so on to elucidate the actual state of rural development in East China district. The research team of the National Institute for Environmental Studies has carried out a series of studies using the. Yangtze River Delta as the study area and focusing on analysis of land uses by viewing satellite images and preparing of a prediction model based on the analysis (Taniguchi 1996; Li et al. 1999). Imura et al. (1999) focused attention on the phenomenon of town-proper expansion in south Jiangsu and pointed out the difference between this case and the case of Shenzhen city, where the urban area expanded along trunk roads from its center.

However, the past studies confined themselves to the prefecture level and have not elucidated changes in land uses at township level over time. Moreover, neither the mechanism of change is analyzed nor the causes peculiar to the region fully identified. Thus, in the present study, elucidation of the actual state of the composition of land uses and change in township was selected as the primary objective. In the study, satellite images taken at five-year intervals from 1980 to 1999 were used as the basic data to avoid the problem of the marked inadequacy of statistical data collected over time. For verification of the results of reading satellite images, the latter were collated with the land-use maps in $1996(1 / 10,000)$ available, and accurate classification of land use was then attempted. Furthermore, field surveys and interviews with the organizations concerned were carried out seven times, in the autumn of 1998 and spring and autumn of 1999, 2000, and 2001. The present author tried to present the whole picture of changes in land uses at township level as much as possible by incorporating the above philological analysis, image analysis and field surveys.

\section{An Overview of Yuqi Township and the Appropriateness of the Area as a Focus of Study}

Yuqi Township is located in the wetlands to the northeast of the city of Wuxi. The boundaries of the township form a rectangle with dimensions of $9.6 \mathrm{~km}$ (north-south) by $6.3 \mathrm{~km}$ (east-west). The township is well-located in terms of access to transportation: it is bisected by a highway linking Shanghai and Nanjing, and just to the south are both a railway line linking Shanghai and Nanjing, and a major road, Route 312 (Figure 1). As of 1999, the precise total area of Yuqi Township was 39.34 $\mathrm{km}^{2}$. It was controlled by 17 village administrations and a "Residents' Committee" (the latter representing individual residents of the township and one business, a fish hatchery). The total number of households was 14,692 , with a total township population of 43,530 (of which 21,915 comprised the township's working population).

Since the early 1980s, economic growth has focused on metalworks and textiles, and the growth has been substantial: in 1983, the township was one of only seven in the entire country to achieve an overall industrial/agricultural output of more than 100 million yuan. Output steadily rose thereafter, reaching 1 billion yuan in 1992 and 34.7 billion yuan in 1999 .

Yuqi Township made pioneering efforts (aided by the significant improvement in its 


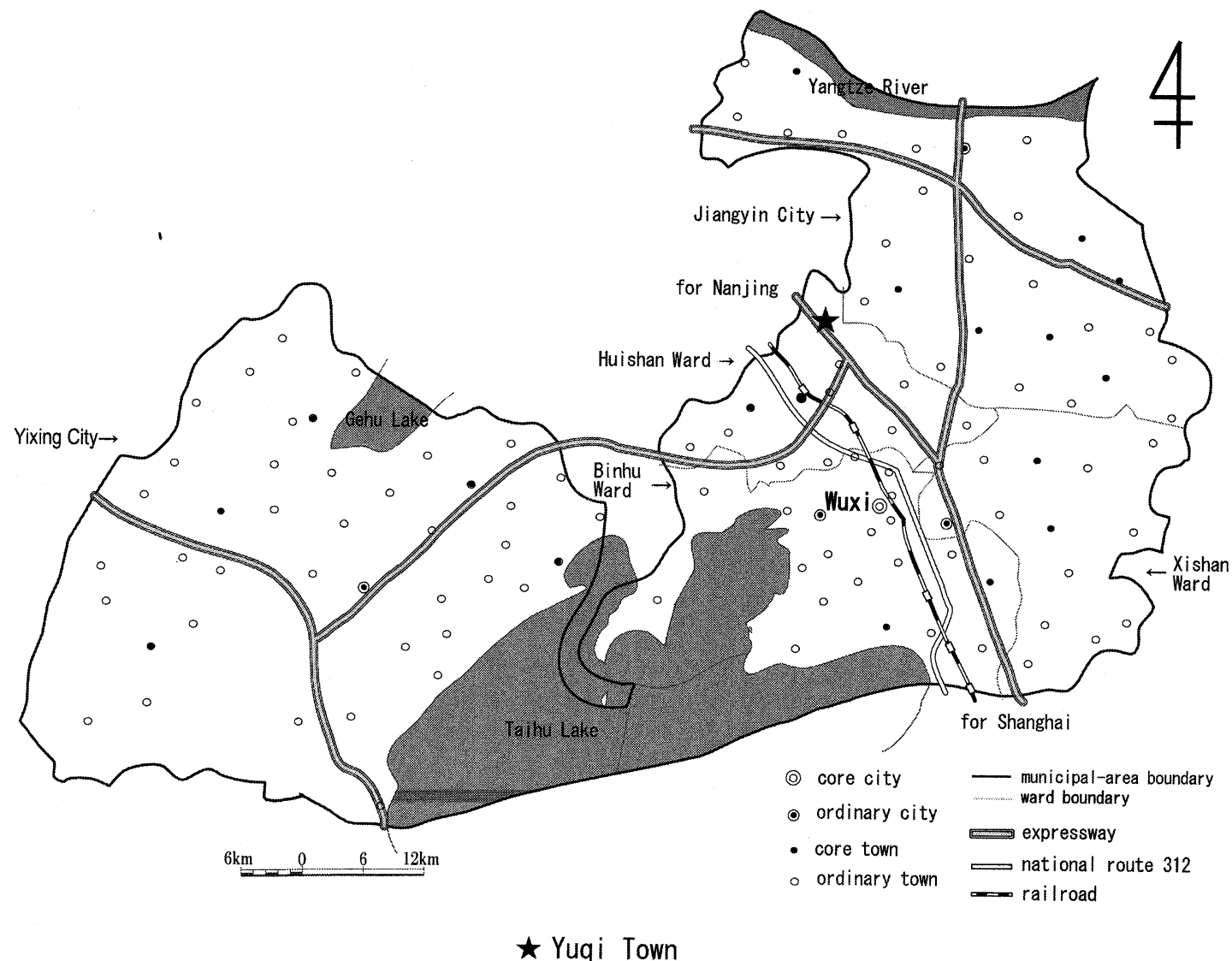

Figure 1. Geographical sketch of the case study area.

economic circumstances) in the area of balanced local development by strict adherence to an overall plan. In doing so, the township became a model for the rest of the country: in 1994, it was designated "Model Township for Development in Smaller Administrative Units of Jiangsu Province" (one of 100 in the province); in 1997 it was not only selected as one of just 34 "New-Type Model Townships" in Jiangsu Province, but was also designated by the national government's Ministry of Construction as a "Pioneer Township in the Area of Smaller-Administrative-Unit Development." Most recently, in 1999, it was selected as one of the "Core Townships" slated for selective infrastructure development, and because of its impressive record in the area of land-use management was honored with the designation "Land Management Model Township."

Yuqi Township possesses certain characteris- tics which suggested that it would be particularly appropriate as the focus of the present study. Located $20 \mathrm{~km}$ from the nearest urban centers, it has not been influenced significantly by urbanization pressures. At the same time, it lies on a plain, and thus the expansion potential for built-up areas is not restricted by adverse geographical features. It is also unique administratively, in being the only one of the seven "Core Townships" in the former municipality of Xishan to have no offices of any higher-level administrative organs (such as the Tax Bureau or the police) in it. The development which can be observed there can therefore be said to be a genuine expression of the local will alone: taking into account purely local conditions and future needs, the township authorities created and implemented plans for the most effective use of local land and for local development. 
Table 1. Changes in land use by category during the 1990s in Yuqi Township

units: hectares

\begin{tabular}{lccccccccc}
\hline & Total & Cropland & Orchards & Forest & $\begin{array}{c}\text { Housing/mining } \\
\text { and industry }\end{array}$ & $\begin{array}{c}\text { Transportation } \\
\text { routes }\end{array}$ & Water & Unused \\
\hline 1993 & A & 3934 & 2127 & 20 & 9 & 635 & 188 & 923 & 26 \\
1996 & B & 3934 & 1999 & 15 & 9 & 705 & 235 & 945 & 26 \\
1999 & C & 3934 & 1988 & 14 & 9 & 727 & 236 & 936 & 24 \\
\hline \multicolumn{2}{c}{ C-A } & & -139 & -6 & 0 & 92 & 48 & 13 & -2 \\
\hline
\end{tabular}

Source: Materials at Yuqi Township National Land Management Bureau office, October 2000.

\section{Changes in Land Use in Yuqi Township}

Table 1 illustrates the changes in land use in Yuqi Township which occurred between 1993 and 1999. In the course of these six years, 139 ha of cropland and 6 ha of orchards, together with 2 ha of disused land, were transformed into housing areas and areas for mining/manufacturing (92 ha in total for these two categories) as well as zones for transportation routes (48 ha) and other purposes.

Due to the difficulties in obtaining data which would allow them to fully appreciate the spatial dimensions of changes in land use, the present author chose to supplement their statistical findings with satellite images. They obtained Landsat TM images of Yuqi Township generated on August 4, 1984, February 26, 1990, August 3, 1995, and February 3, 1999, and processed them using "ERDAS Imagine" software. After scanning maps indicating the boundaries of all the townships in the former municipality of Xishan, and matching the Landsat images to them, they were able (with geometric correction) to find the precise areas under examination in this study. They then analyzed each image and broke down what they observed into three categories: urban areas, rural areas, and areas of water (Figure 2).

A number of significant changes which have taken place since 1984 can be readily grasped from the satellite images. Comparing the 1984 and 1990 images, we can see how one of the key infrastructure elements for township development was put into place by improving the road network, and the way in which the township gradually expanded to the southeast. When the images from 1990 and 1999 are compared, sev- eral more recent major changes become clear: it is quite evident that there was a significant increase in the amount of land used for urban development in the area immediately surrounding the town proper; the pockets of population concentration which could be found scattered along the riverbanks in 1990 had been consolidated and relocated along either side of major roads, in particular the road to Wuxi; the area covered by water and paddy had significantly decreased due to improvements made in the roads and waterways, and the development of fields for crops; new roads had been built in conjunction with the construction of an expressway linking Shanghai and Nanjing which cut across the township.

The present author was also able to obtain a $1: 10,000$ land use map of 1996 in Yuqi Township. From the information contained on the map, as well as satellite images providing clear visual evidence of land use in the township, they were able to determine the following: (1) the built-up area could be broken down thus: $60 \%$ was housing, $28 \%$ industry-related, and $12 \%$ township and village roads; ${ }^{4}$ (2) while land for factory use existed in all village areas, the larger-scale facilities were concentrated in the area immediately surrounding the town proper and to the south; (3) public facilities and institutions tended to be concentrated in the town proper, with the exception of elementary schools, which could be found in every village. Of interest in connection with the issue of development in the town proper versus that in villages is the fact that, between 1996 and 2001, the area of the town proper increased by 110 ha, while that of the built-up areas in villages increased only by 3.2 ha in total. 

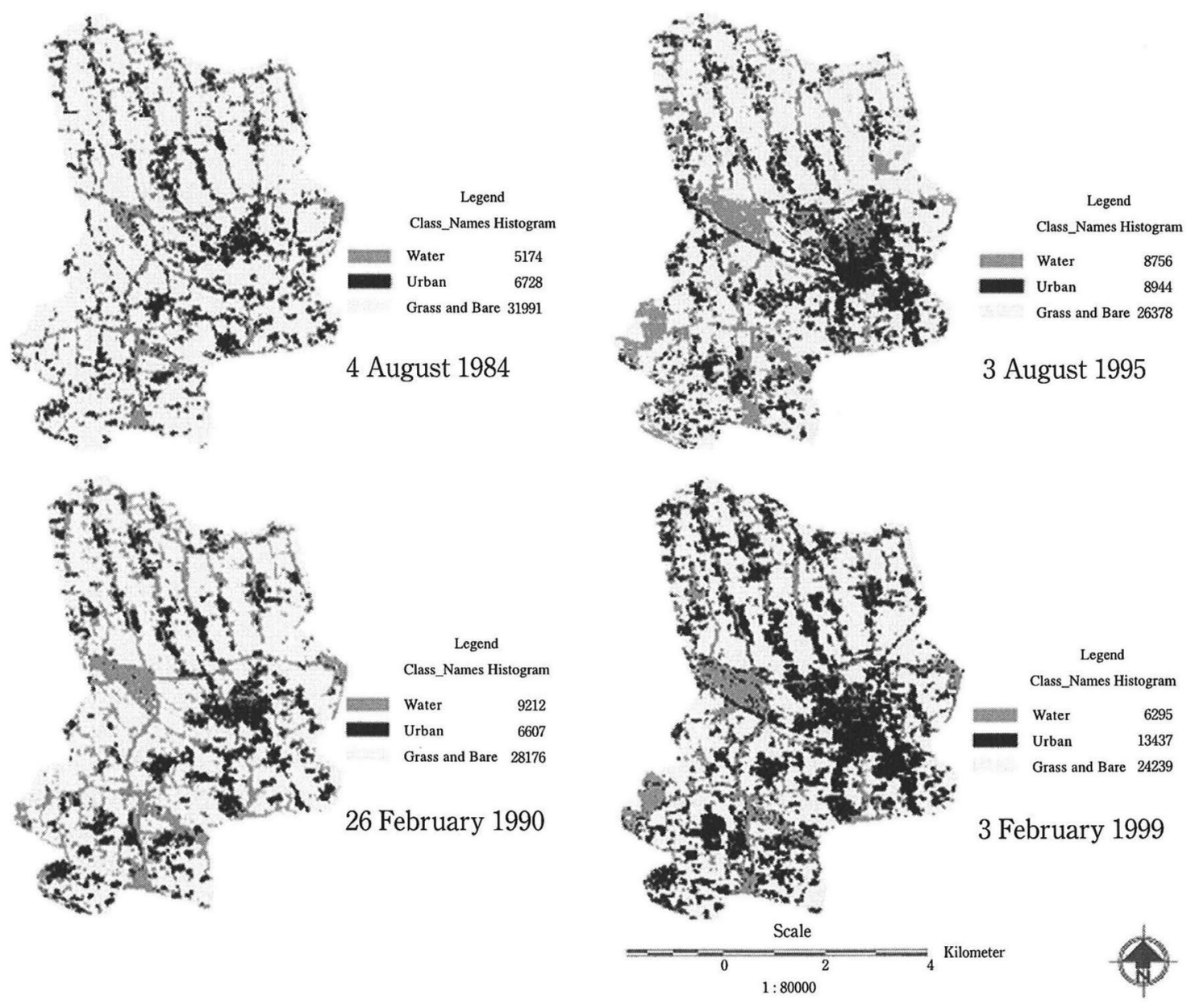

Figure 2. Changes in categorization in Yuqi Township, 1984-1999.

Figures are pixels $\left(1\right.$ pixel $\left.=30 \mathrm{~m} \times 30 \mathrm{~m}=900 \mathrm{~m}^{2}\right)$.

\section{Mechanisms of Land-Use Changes}

\section{Action taken with the government in the lead}

During the 1980s, the Township pushed forward the industrialization of rural areas by forming an "Umbrella Industrial Enterprise" using public funds. At the same time, part of the profits made by local firms was utilized for the purpose of restructuring land use in the Township.

In 1987 Yuqi Township, taking into consideration its advantageous location bordering the three cities of Jiangyin, Wujin, and Xishan, adopted as its guiding policy a plan to revitalize the area by developing and expanding it to create a zone in which attractive commercial establishments and facilities would be concentrated. The first step was the opening of "Yuqi Township Commercial Place" in March 1988, in which the Township invested 7,830,000 yuan. This zone, about $700 \mathrm{~m}$ from the old town center, covered an area of $3,830 \mathrm{~m}^{2}$, and was intended to be a multi-purpose trading location (both wholesale and retail) for agricultural produce and daily household items. The Township successfully played the roles of both broker for the sale of agricultural produce and distributor of a wide range of items. It also utilized funds saved by the Collective to prepare land for building private housing, and sold such land or individual homes to farmers who had already become wealthy, which promoted an influx of 
such people into the Township. As an additional incentive, these people were offered the chance to switch their registered domicile from the "Rural Residency" category to the "Urban Residency" category if they bought homes in the Township. The latter category was much coveted by those in rural areas, since as permanent residents of the Township they would have access to the full range of benefits and amenities enjoyed by urban dwellers: better educational and health-care facilities, and a good supply of daily necessities not readily available elsewhere in any quantity or variety. There was an additional "price," however: a special levy, called "Contributions to Assist in Urban Improvement." This levy brought a total of 250 million yuan into the Township coffers between 1987 and 1994, all for further infrastructure development.

Yuqi Township introduced for-profit use of land in 1991, and in 1992 a real-estate and housing-development company was created, subject to the authority of the Township government, which would assume responsibility for all aspects of the development plan: designing, implementing, and monitoring. This company's top posts were held by members of the Township government, and beginning in the late 1990s its principal source of funding was the profit from such transactions as the sale of housing units and the transfer of deeds to property. This was a very substantial sum, as the example of 1998 will amply demonstrate: revenues in that year from for-profit use for collectively-held land reached 710,000 yuan, while fees for transferring rights to use land owned by the national government brought in $42,600,000$ yuan, and rental fees for 225 plots totaling 34 ha, another $3,400,000$ yuan. ${ }^{5}$

The Township put its substantial revenues from the new system to work in a number of ways. Fifty percent was devoted to overall improvement of infrastructure throughout the Township, in particular in the town proper. In the last several years, some $70 \mathrm{~km}$ of paved roads have been built, waterworks have been extended to provide service to $100 \%$ of the Township, and 6,700 communications and cable-television lines have been put in; in addition, an interchange on the Shanghai-Nanjing
Expressway, named "Yuqi Township," was built, requiring an investment of $23,000,000$ yuan and 15 ha of land. Within the town proper, a government center, a hospital, a school, a movie theater, a park, a hotel and other buildings have all been built, contributing to the expansion of the area of the town proper from $0.28 \mathrm{~km}^{2}$ (in 1986) to $1.2 \mathrm{~km}^{2}$ in 1993 and to $2.3 \mathrm{~km}^{2}$ in 1999 , as well as to the growth of the population of the town proper from 15,000 in 1988 to nearly 20,000 (including day laborers) in 1999-nearly half the total population of the entire Township.

The changes in industry have been substantial as well. In the late $1990 \mathrm{~s}$, the annual increase in tertiary-industry output grew considerably, from $279,810,000$ yuan in 1996 to $347,190,000$ yuan in 1999, and the tertiaryindustry share of the area's total GDP rose from $28.8 \%$ in 1996 to $36 \%$ in 1999 . The key figures for 1999 are impressive for tertiary industry: an overall industrial output valued at 899,610,000 yuan, 1,170 firms, and 5,740 employees. The Township, pursuing a policy of efficient land use taking into account land value, responded to this growth by moving factories which had been located in the town proper to one of two sites designated as "industrial zones" (one near the expressway interchange to the south, the other just north of the town proper), concentrating tertiary-industry activities such as finance and distribution in the town proper, and creating spaces for constructing high-quality housing at the former sites of some factories and in the outskirts of the town proper. This last step contributed to an increase in the permanent population of the town proper to 14,800 , fully $74 \%$ of the total of 20,000 .

\section{Inducement via the land-use plan}

An outline of the plan The "Comprehensive Plan for Land Use in Yuqi Township, 19972010 " is considered to be the ultimate determiner of land-use activity in Yuqi Township through 2010, incorporating all the fundamental elements of a number of other plans: the "Basic Plan for Preservation of Agricultural Lands, 1991-2000" from the agricultural sector; the "District Plan, 1996-2010" and "Township Plan, 1996-2010" from the construction sector. 
Table 2. Yuqi Township plan for land for agricultural use (1997-2010)

\begin{tabular}{|c|c|c|c|c|c|c|c|}
\hline & \multicolumn{4}{|c|}{ Land added under Plan } & \multicolumn{2}{|c|}{$\begin{array}{l}\text { Reduction in amount of } \\
\text { land for agricultural use }\end{array}$} & \multirow{2}{*}{$\begin{array}{l}\text { Increase or } \\
\text { reduction in } \\
\text { amount of } \\
\text { land for } \\
\text { agricultural } \\
\text { use A-B }\end{array}$} \\
\hline & $\begin{array}{l}\text { Land } \\
\text { restored to } \\
\text { agricultural } \\
\text { use }\end{array}$ & $\begin{array}{c}\text { Through } \\
\text { farmland } \\
\text { consolidation }\end{array}$ & $\begin{array}{c}\text { Through } \\
\text { consolidation } \\
\text { of rural } \\
\text { communities }\end{array}$ & Total A & $\begin{array}{c}\text { Land for } \\
\text { development }\end{array}$ & Total B & \\
\hline $1997-2000$ & 3.33 & 46.67 & 8 & 58 & 22.26 & 22.26 & 35.34 \\
\hline $2001-2005$ & 3.47 & 53.33 & 9.27 & 66.07 & 25.94 & 25.94 & 40.13 \\
\hline 2006-2010 & 1.86 & 33.34 & 5.93 & 41.13 & 16.33 & 16.33 & 24.8 \\
\hline $\begin{array}{l}\text { Increase or } \\
\text { reduction in } \\
\text { amount of } \\
\text { agricultural } \\
\text { land under } \\
\text { the Plan }\end{array}$ & 8.66 & 133.34 & 23.2 & 165.2 & 64.93 & 64.93 & 100.27 \\
\hline
\end{tabular}

Source: Plan for Lang Use in Yuqi Township, 1997-2010. Municipality of Xishan, Yuqi Township, unpublished, 1998, p. 40.

Its purpose is to promote the reorganization of land use in such a way that there will be three areas of concentration: an area exclusively for agricultural production, another utilized as an industrial district, and a third (the town proper) where the population will be centered.

Total area of cropland and the securing thereof Table 2 details the plan for securing the land for agricultural use. By 2010, the amount of such land is to be increased by 100.27 ha from its 1996 level of $1,999.4 \mathrm{ha}$, yielding a total of $2,099.67 \mathrm{ha}$. This is to be accomplished by adding some land previously utilized as orchards or woodlands, as well as some disused land (an additional 8.66 ha in total), making improvements and alterations at existing agricultural-use plots (expected to add $133.34 \mathrm{ha}$ ), and freeing up land by consolidating communities (expected to add another 23.2 ha). Of the new total of $2,099.67$ ha, 186 plots, with a total area of $1,739.33$ ha, will be designated "Primary Agricultural Land," which will make it legally impossible to utilize this land for non-agricultural purposes thereafter. Another $202.13 \mathrm{ha}$, comprised of 58 parcels of land, will be considered "General Agricultural Land" and will be preserved for crop use as well. The grand total of these 2 categories will make up $94.12 \%$ of the land for agricultural use. An additional 121.32 ha, covering 58 parcels of land, will not be utilized for agricultural pur- poses but will be designated "Land Slated for Development" and held in reserve to meet the needs of future urban development.

Restructuring the housing system In 1996, the Township contained 137 pockets of settlement. These pockets are a prime target of the new land-use plans: by 2015, Yuqi Township is to be restructured into one "town proper" (or "town center") with a population of 45,000 , four "core villages" (population 12,000), and seven "outlying villages" (population 7,000; two of these are to have been completed by the year 2000 , and another three by the year 2015). As a result of such restructuring, additional land will be freed up for agricultural use ( 8 ha by 2000, another 15.2 ha between 2001 and 2010 , for a total increase of $23.2 \mathrm{ha}$ ), and the amount of land used in the villages for housing will decrease from a 1996 total of 316.17 ha to 268 ha by 2010 .

The Township has adopted certain policies to ensure the smooth implementation of its restructuring plans. One is the policy of encouraging resettlement in the town proper by giving those who express an interest in moving there priority in selecting their housing units, and selling them the units at the reduced price of 1,050 yuan per square meter (rather than the going rate of 1,200). Another policy prohibits any further construction of housing in settlements of 50 dwellings or less which do not take 
steps to merge with other settlements by 2010 in accordance with the directives in the Plan.

Achieving a high level of efficiency in land use One element in the promotion of efficient land use has been the move away from the construction of single-family dwellings in the town proper and surrounding villages. The Township has placed restrictions on the building of individual homes while actively promoting the construction of five- and six-story apartment buildings. As a result of this policy, eight areas within the Township were developed for such large-scale housing use between 1995 and 2001, beginning with the "Yucai Housing Area"; they occupied a total of 10 ha. As of 2002, 30 five- and six-story apartment buildings existed in the town proper on this land.

The shift of the population into large-scale housing units in the town proper has proceeded smoothly. In 1997 and 1998, 1,000 people moved into the 1,000 existing condominium units; between 1999 and 2002, 3,000 more did so. Of these people, 1,400 were previously inhabitants of the town proper, 40 were from outside Yuqi Township, but a full 64\%, 2,560 people, had previously lived in rural districts of the Township, indicating the degree to which the Township's plans have succeeded in achieving their desired effect.

Due in part to the concentration of the population in large-scale housing in the town proper, the amount of land utilized for industrial and housing purposes is expected to shrink from a 1996 level of $121.3 \mathrm{~m}^{2}$ per capita to less than $100 \mathrm{~m}^{2}$ by 2010 .

Practical application of the municipal directives on diversion of farmland to other uses Evidence clearly suggests that Yuqi Township is carrying out in an effective manner the annual directives of the Xishan municipal government regarding amounts of land to be diverted from farm use to other uses. In 2000, for example, to fulfill a target of $13 \mathrm{ha}$, the Township allotted 6.5 ha each to two areas for industrial zones: the village of $\mathrm{Sg}$, near the Shanghai-Nanjing Expressway interchange, and the villages of $\mathrm{Rz}$ and $\mathrm{Rn}$, just to the north of the "town proper." After readying the two areas for use as industrial zones, the Township relocated industrial operations from the town proper to the zones, and did so in very rational fashion: light industry not likely to be very harmful to the environment (such as spinning) was relocated to the village of $\mathrm{Sg}$, which is upwind of the town proper; operations which produced pollution, such as factories making steel plates and aluminum window frames, and breweries, were relocated downwind in the villages of $\mathrm{Rz}$ and $\mathrm{Rn}$. By adopting such approaches to land-use restructuring, the Township resolves the problems resulting from housing and industry existing in close proximity to one another, and it also facilitates the efforts of the town proper to make a transition from manufacturing center to tertiary-industry zone. Furthermore, it rationalizes population distribution by consolidating widely-scattered pockets of settlement and creating core areas of population concentration (Figure 3).

\section{Conclusion}

The above has been an attempt to characterize the situation in Yuqi Township regarding the manner of inducing compliance with the Township plan for bringing about changes in land use, and the nature of the changes themselves. The findings can be summarized as follows:

1) Two stages can be identified in the landuse changes. In the first stage, during the 1980s, the Township supplied local enterprises with land practically free of charge, utilizing the mechanisms of the collective economy, and then used part of the profits derived from the resulting industrial output to expand and develop the "town proper." The second stage began in the late 1990s, when market-economy principles had taken full effect; at this time, the Township set up a real-estate and housingdevelopment company, putting itself in the position of developer, and also approved private investment in real-estate-related activities. To maximize the number of sources of funds for development of the town proper, the Township actively adopted what might be called an "allencompassing" approach, not only utilizing public funds but also encouraging investment by the private sector and even individuals. It should be noted, however, that throughout the 


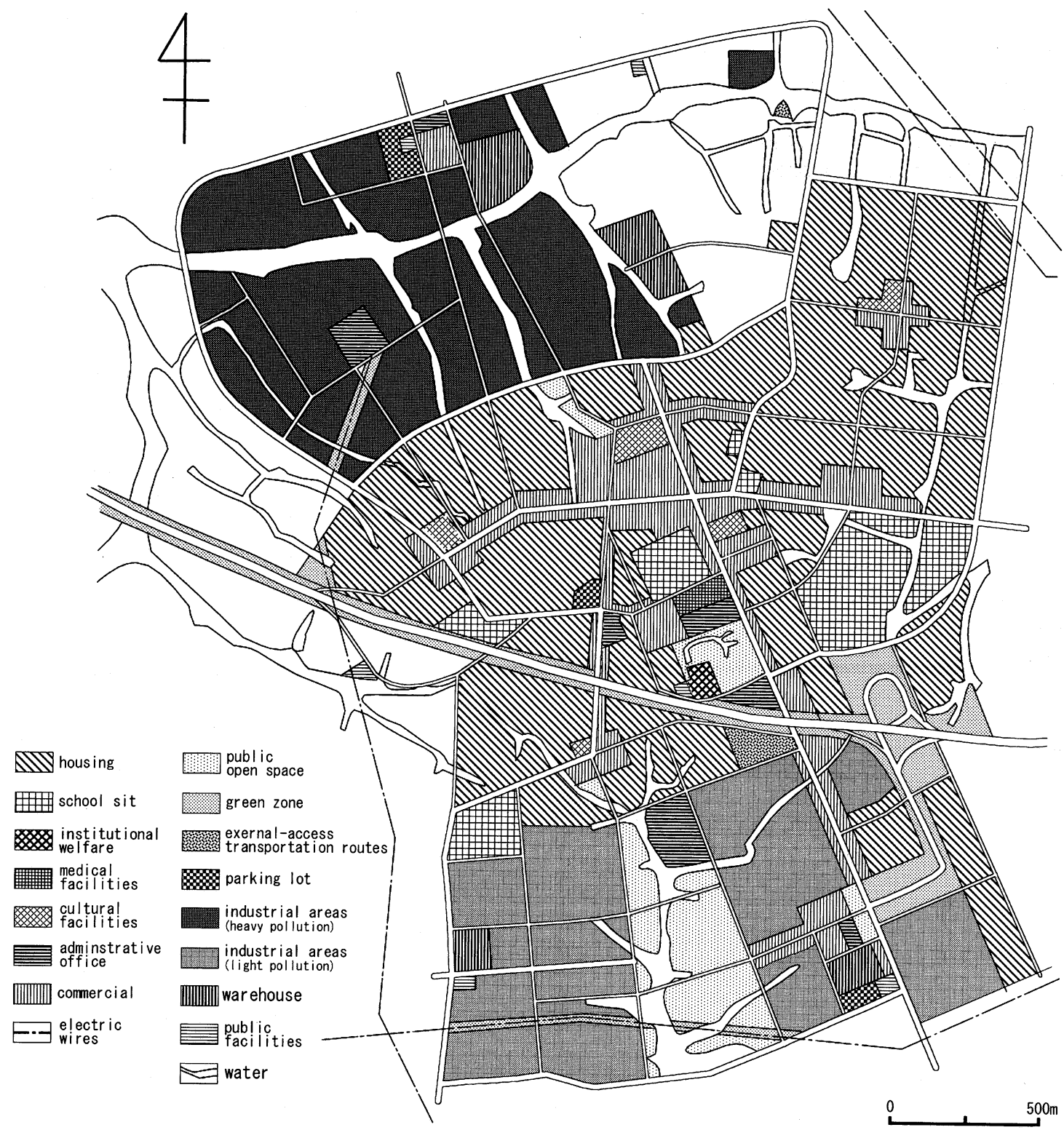

Figure 3. Map indicating plan for land use in the Town Proper, Yupi Township, for 2000-2015. Source: Comprehensive Plan for Yuqi Township, Municipality of Xishan, Tongji University, Yuqi Township, 2000.

two stages it was still the Township government which played the key roles of formidable "persuader" and ultimate "fixer."

2) In the final analysis, the changes which have occurred in land use within Yuqi Township are the result of activities and efforts on the part of a number of different players, foremost among them: the government, with its land-use plans, regulations, and active inducement; the private sector, with its substantial financial investments; the local populace, responding to the changing situation on the basis of what it felt would benefit or harm it. At the same time, the advance of the market into every facet of economic life, land-use matters included, has significantly altered attitudes toward land in general: the market mechanism now determines how much land is worth, and consequently how it will be used, and what constitutes "efficient" use of it. 
3) Analysis of the course taken from the 1980 s onward clearly indicates that the principal focus of the Plan and of actual development has been the construction of a quality road network and the laying of groundwork for development in the town proper. In the case of the latter, priority was given to the preparation of land for industrial use; expansion of industry in turn led to an expansion in housing construction as people moved into the area to be close to their workplaces. The growth of the population of the town proper then created greater demand for tertiary-sector activities, making the town proper more and more focused on that sector. In the last several years, improvements to the overall living environment of the town proper which will be of long-term, lasting value have come to be viewed as important; waterworks, a processing plant for polluted water, green zones, parks, and entertainment facilities for the growing number of elderly have all been built recently.

4) While land-management regulations have been made stricter, so that development not in accordance with the Plan is not permitted, what should be noted is the largely autonomous nature of many land-use changes, based on perceived benefits to the society at large. Also of note is the direction in which the still-veryactive government intervention (inducing participation in and cooperation with the Plan, making changes in the latter, and the like) will take matters.

5) Naturally enough, changes in land use will vary from region to region. In order to fully understand this phenomenon and construct an accurate model of the process of urbanization of rural areas in China, it is necessary to conduct analyses of other regions of the Yangtze Delta, utilizing the same methods and the same perspectives as in the present study of Yuqi Township.

\section{Acknowledgments}

My deepest thanks are due to Yasutomi Nakano, a graduate student at the Agricultural Research Department in Kyoto University, for processing the satellite images used here.

(Received 25 April 2003)

(Accepted 31 July 2004)

\section{Notes}

1. In China, "Urban population" includes the populations of the cities and the rest of the Township.

2. In March 2001, the city of Xishan was annexed to the city of Wuxi.

3. For example, Proceeding of study reports on small towns of Jiangsu Province by Jiangsu Province People's Publisher: (1) Small towns: Serious problems, 1984; (2) Small towns: New development, 1986; (3) Small towns: Rerecognition, 1989; (4) Small towns: New land, 1991; (5) Small towns: Over the centuries, 1998.

4. Tongji University and Yuqi Township. 1996. Regional plan for Yuqi Town, municipality of Xishan, p. 13 (in Chinese). The statistics are as of 1993.

5. Revenues for Yuqi Township in 1998 were $60,410,000$ yuan.

\section{References}

Imura, H., Chen, J., Kaneko, S., and Matsumoto T. 1999. Analysis of industrialization, urbanization and land-use change in East Asia according to the DPSER framework. Proceeding of 1999 NIES Workshop on Information Bases and Modeling for Land-use and Land-cover Changes Studies in East Asia. 227-234.

Ji, Z. M., and Torii, K. 1999. Regional development and land-use change in the Yangtze River Delta. In Study on the processes and impact of land use change in China, Report V, ed. K. Otsubo, 55-71. Tsukuba: National Institute for Environmental Studies (Japan). (J)

Ji, Z. M., and Torii, K. 2000. Expansion of the town center in the rural areas of the Yangtze River Delta and its mechanism: A case study of towns in Xishan City, Jiangsu Province. In Study on the processes and impact of land use change in China, Report VI, ed. K. Otsubo, 83-108. Tsukuba: National Institute for Environmental Studies (Japan). (J)

Ji, Z. M. 2001. The progress and the problems of the development of small towns in agricultural regions of China: Construction of peasants' cities, by peasants, for peasants. Journal of Sugiyama Jogakuen University, Social Sciences 32: 65-83. (J)

Ji, Z. M. 2002. An analysis of urbanization in rural areas of China using images: A case study of development of towns in Xishan City, Jiangsu Province. Journal of Sugiyama Jogakuen University, Social Sciences 33: 61-79. (J)

Li, L., Sato, Y., and Otsubo, K. 1999. Modeling of urban expansion based on satellite image data. 
National Institute for Environment Studies LU/ GEC Project report -Mechanism of the longrange change in land uses in China and its infuence-. 122-132.

Nian, F. H., and Yao, S. M. 2002. Developmental trends in the urbanization of China in the $21^{\text {st }}$ century. Journal of Science and Technology 1: 5356. (C)

Taniguchi, M. 1996. Results and discussion about construction of urban model in the downstream of Yangtze River: Change in land uses in the downstream of Yangtze River. A long-range prediction of changes in land uses and land covers in Asia and Pacific Regions (1), LU/GEC Project Team, 72-85.
Tanimura, M. 1995. Results and problems associated with development and management of villages in China-Residential development in villages in East China district, with preparation of infrastructures as an example. International Development Study Forum 3: 49-60.

Zhai, K., Ikeda, S., and Itakura, H. 1999. Structural analysis of the change in land uses in the downstream of Yangtze River-Statistical analysis by the two-way layout model. Geographical Review of Japan 72: 600-617. (J)

$(\mathrm{J})$ : written in Japanese

(C): written in Chinese 